\title{
Sett av dato 13.-15. april 2016!
}

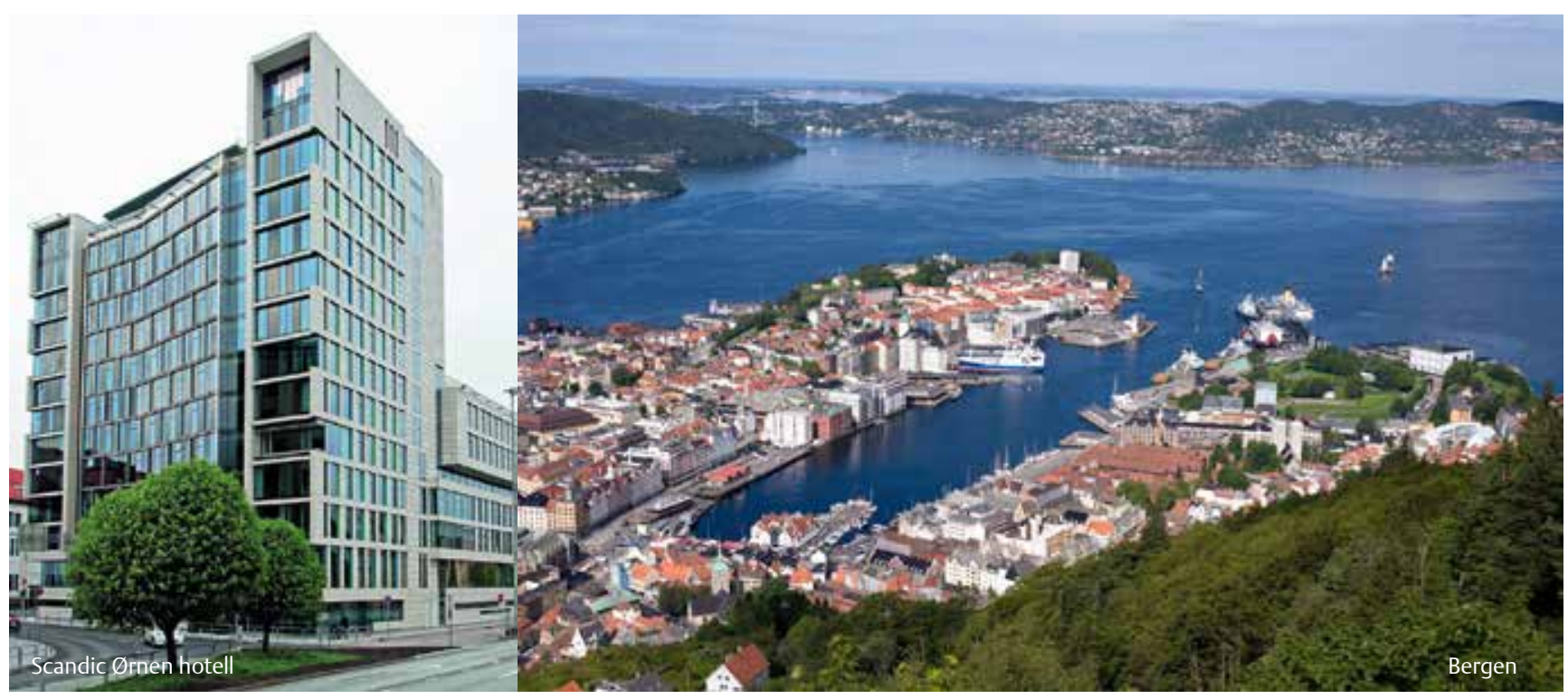

I 2016 arrangeres NUFD sitt årlige symposium i Bergen i perioden 13.-15. april. Møtested er Scandic Ørnen hotell i Bergen. Styret holder på med å sette sammen et variert program fra fagområdene radiologi, revmatologi, muskelskjelett, indre medisin og gastroenterologi, gynekologi og obstetrikk, akutt- og allmennmedisin.

Onsdagen fra kl. 10.30 til kl. 17.30 er etter fjorårets hovedsakelig positive tilbakemeldinger igjen avsatt til Basalkurs i ultralydfysikk og apparatlære. Kurset omfatter ultralydfysikk og „knottologi“, artefakter i ultralydbilde, Doppler, sikkerhet og dokumentasjon ved ultralyd og praktisk undervisning på stasjoner „Abdomen“, „Akuttmedisin“, „Obstetrikk/gynekologi“, og „Ultralydveiledet intervensjon“.

Kurset inneholder tverrfaglig grunnleggende opplæring, som skal danne basis for fordypning i flere medisinske ultralydspesialiteter og gir dermed grunnlag for eget kursbevis.

På torsdagen lanseres et nytt tilbud med eget kursbevis. Programmet for akutt- og allmennmedisin tilbyr FATE - Focus assessed transthoracic echocardiography, FAST - Focused Assessment with Sonography in Trauma og HOT - Hands On Training. Etter en teoretisk innføring skal det være fokus på praktiske øvelser under veiledning av erfarne instruktører.

Nærmere informasjon om programmet legges etter hvert ut på nettsiden http://www.nfud.no/.

Har du et spennende prosjekt eller kasuistikk innenfor ultralyd, er du velkommen til å presentere dette i form av et fritt foredrag. Beste frie foredraget honoreres med 10000 NOK.

Styret vil samtidig minne om forskerstipendiet på 10000 NOK, som utløses årlig av NFUD i forbindelse med symposiet. Vi oppfordrer derfor alle, som er i gang med eller planlegger prosjekter innen ultralyd, om å søke.

15. mars 2016 er frist for både påmelding, innsending av abstrakt og søknad om forskerstipend. 